\title{
Progression of Treating Alzheimer's Disease with Stem Cell-based Therapies
}

\author{
Jigishu Ahmed*, Md. Hafizur Rahman \\ Department of Clinical Hematology and Cancer Biology, International Centre for \\ Diarrhoeal Disease Research, Bangladesh (icddrb)
}

* Corresponding author email: jigishuahmed@hotmail.com

Received: 08 July 2019 / Accepted: 24 July 2019 / Published: 28 July 2019

\begin{abstract}
Alzheimer's disease is one form of dementia affecting a significant proportion of the population. The etiology of this prevalent disease is currently unknown. It is postulated that AD can be treated by using stem cell-based therapies by replacing the lost neurons in the atrophic regions of the brain. For these novel therapies to be successful several sources of stem cells have been proposed, such as pluripotent stem cells as well as multipotent stem cells. Proof of concept in animal studies have shown that stem cells can grafted into the affected regions or delivered intravenously into affected parts of the brain. These experiments had improved cognition and memory performance in rodents. The promising results seen in animal models have increased interest in conducting clinical trials using the same technique. In the last 5 years, several treatments have reached phase II clinical trials.
\end{abstract}

Keywords: Alzheimer's disease, dementia, neurodegenerative disease, stem cell based-therapies, stem cell-based treatments, stem cells

\section{Introduction}

The prevalence of dementia is a major concern for the public health agencies all over the world. Current estimates state over 50 million people suffer from dementia globally and is expected to increase due to ageing of the population [1]. One form of dementia is due to Alzheimer's disease (AD), which is one of the leading causes of death in the United States [2]. The disease is characterized by significant atrophy in the subcortex and cerebral cortex. In the early stages of the disease patients display mild cognitive impairment, such as having problems with their short-term memory, semantic memory etc. As the disease progresses patients have shrinking vocabulary, problems communicating and the loss of long-term memory. In the advanced stages the patients become bedridden and unable to take care of themselves (Table 1) [3].

$\mathrm{AD}$ is classified as early onset or late onset, the latter constitutes of most of the $\mathrm{AD}$ cases. A significant proportion of early onset $A D$ is familial and is manifested due to mutations in three genes: amyloid- $\beta$ precursor protein $(\mathrm{A} \beta \mathrm{PP})$, presenilin-1 (PS-1) and presenilin-2 (PS-2) [4]. Gene knockout studies have shown that APP is involved in synapse formation [5]. Moreover $\mathrm{A} \beta \mathrm{PP}$ is a precursor molecule that is further cleaved by secretases (such as alpha-secretase, beta secretase and gamma secretase). When $\mathrm{A} \beta \mathrm{PP}$ is cleaved by $\beta$-secretase and $\gamma$-secretase amyloid beta $(A \beta)$ is formed [6].

Currently the pathology of the disease is heavily debated. One of the premises of the disease is called the amyloid hypothesis, with the latest iteration being referred as the ion channel hypothesis. The notion of the hypothesis is that non-fibrillar and soluble $A \beta$ oligomer is the most neurotoxic by forming membrane ion channels in the neurons. This allow unregulated calcium influx, leading to neuronal death [7], [8]. However not all AD diagnosed patients show presence of A $\beta$. This can be exemplified by Doraiswamy's 
and colleague's research conducted at Harvard. By using a molecule that binds to $A \beta$ called Florbetapir they showed that PET scans of one third of $A D$ patients recruited in the study did not show signs of $A \beta$ in their PET scans [9]. Moreover pharmacological targets identified by adhering to the amyloid hypothesis lead to failed clinical outcomes in clinical trials. In one phase I clinical trial of an experimental vaccine (AN1792) for clearing up amyloid plaques failed to slow down the progression of AD [10]. Recent phase III clinical trials have followed the same trend. Verubecestat, which inhibits $A \beta$ production by acting as an inhibitor for $\beta$-secretase, has failed in a phase III clinical trial [11], [12]. Similarly, a biologic was promising in animal models of $\mathrm{AD}$ but a phase III drug trial was terminated early due to lack of evidence [13]. Because of failure of drug development for treating $\mathrm{AD}$ there has been a renewed interest in stem cell-based therapies. In this review we will discuss the different sources of stem cells that can be used, proof of concept experiments using animal models and finally explore clinical trials being conducted on stem cell-based treatments for AD.

Table 1: Progression of symptoms in AD. Adapted from Alistair Burns \& Steve [3].

\begin{tabular}{|c|c|}
\hline Disease stage & Symptoms \\
\hline $\begin{array}{l}\text { Mild Alzheimer's } \\
\text { disease }\end{array}$ & $\begin{array}{l}\text { Short term memory loss, } \\
\text { problems with semantic } \\
\text { memory, forgetfulness, } \\
\text { repetitive questioning }\end{array}$ \\
\hline $\begin{array}{c}\text { Moderate Alzheimer's } \\
\text { disease }\end{array}$ & $\begin{array}{l}\text { Dysexecutive syndrome, } \\
\text { showing cognitive } \\
\text { deficits }\end{array}$ \\
\hline $\begin{array}{c}\text { Severe Alzheimer's } \\
\text { disease }\end{array}$ & $\begin{array}{l}\text { Assistance required in } \\
\text { everyday tasks, } \\
\text { bedbound altered sleep } \\
\text { pattern, agitation, no } \\
\text { language skills }\end{array}$ \\
\hline
\end{tabular}

\section{Sources of Stem Cells}

Stem cells are undifferentiated cells that have the ability to differentiate into specialized cells or replicate to generate more stem cells. They can be grouped into two types: pluripotent or multipotent according to their potential for differentiation. Examples of pluripotent stem cells are embryonic stem cells (ESCs) and induced pluripotent stem cells (iPSCs) whilst examples of multipotent stem cells are neural stem cells (NSCs), mesenchymal stem cells (MSCs) etc (Table 2).

In vivo 5-6 days post fertilisation ESCs are located in a clump of cells called inner cell mass of the developing embryo. At this point the embryo is at the preimplantation stage. Scientists do not have to harvest ESCs embryo inside the womb as these embryos can be fertilized in vitro and expanded in culture indefinitely [14]-[16]. These ESCs can be made to differentiate into neurons and other cells found in the brain parenchyma, such as the glial cells. In fact ESCs can be specified into neurons in several ways. One approach for specifying ESCs into neural progenitors would be to culture ESCs in the presence of fetal calf serum augmented by basic fibroblast growth factor and epidermal growth factor [17], [18]. Similarly another efficient method of differentiating ESCs neurons involves stromal feeder cells or retinoic acid [19]. Recently a technique was developed of differentiation involves manipulating Sonic Hedgehog signaling. In this specific case ESCs are differentiated into cortical neurons by using a inhibitor for sonic hedgehog called cyclopamine [20].

iPSCs are one form of pluripotent stem cells and thus have the potential to form all three germ layers. These are somatic cells that have been reprogrammed into a pluripotent state. iPSCs were first created by Yamanka and his group, demonstrating that fibroblasts can be converted into a stem-like state after adding four transcriptional factors: Oct3/4, Sox2, c-Myc, and Klf4 [21]. Later Yamanaka and others have shown that other types of somatic cells (such as hepatocyptes, t-cells, etc.) can also be reprogrammed into iPSCs [22], [23]. One group based in has demonstrated that somatic lung fibroblasts can be reprogrammed into iPSCs by using Oct4, Sox2, Klf4 and c-Myc (the same transcription factors used by Yamanaka et al). Once successfully reprogrammed these iPSCs can be specified into neural fate by blocking SMAD signaling with SMAD inhibitors, such as Noggin and SB431542 [24]. 
Table 2: Potential sources of stem cells for treating Alzheimer's disease.

\begin{tabular}{|c|c|c|c|c|c|c|}
\hline Study & [18] & [20] & [24] & [28] & [29] & [35] \\
\hline $\begin{array}{l}\text { Type of } \\
\text { stem cell }\end{array}$ & $\begin{array}{c}\text { Embryonic } \\
\text { stem cells } \\
(\text { ESCc) }\end{array}$ & $\begin{array}{c}\text { Embryonic } \\
\text { stem cells } \\
\text { (ESCs) }\end{array}$ & $\begin{array}{l}\text { Induced } \\
\text { pluripotent } \\
\text { stem cells } \\
\text { (iPSCs) and } \\
\text { embryonic } \\
\text { stem cells } \\
\text { (ESCs) }\end{array}$ & $\begin{array}{l}\text { Neural stem } \\
\text { cells (NSCs) }\end{array}$ & $\begin{array}{l}\text { Neural stem } \\
\text { cells (NSCs) }\end{array}$ & $\begin{array}{l}\text { Mesenchymal } \\
\text { stem cells } \\
\text { (MSCs) }\end{array}$ \\
\hline Method & $\begin{array}{l}\text { Mouse ESC 4- } \\
\text { day aggregates } \\
\text { cultured in } 5 \\
\times 10^{-7} \mathrm{M} \\
\text { retinoic acid }\end{array}$ & $\begin{array}{l}\text { Mouse ESCs } \\
\text { cultured in } \\
\text { serum-free } \\
\text { and } \\
\text { morphogen } \\
\text { free } \\
\text { chemically } \\
\text { defined } \\
\text { default } \\
\text { medium at low } \\
\text { density in the } \\
\text { presence of } 1 \\
\mu \mathrm{M} \\
\text { cyclopamine. }\end{array}$ & $\begin{array}{l}\text { Monolayer of } \\
\text { ESCs or } \\
\text { iPSCs induced } \\
\text { into neural } \\
\text { fate by Noggin } \\
\text { and } \\
\text { SB431542. }\end{array}$ & $\begin{array}{l}\text { NSCs seeded } \\
\text { on poly-L- } \\
\text { lysine coated } \\
\text { dish } \\
\text { differentiated } \\
\text { into neurons in } \\
\text { the presence } \\
\text { of } 100 \mathrm{ng} / \mathrm{ml} \\
\text { of interferon- } \gamma \\
(\text { IFN- }-\gamma) \text {. }\end{array}$ & $\begin{array}{l}\text { Culture NSCs } \\
\text { in the presence } \\
\text { of } 50 \mu \mathrm{M} \text { of } \\
\text { Baicalin }\end{array}$ & $\begin{array}{l}\text { Culture cells } \\
\text { in the presence } \\
\text { of } 1 \mathrm{mM} \beta \text { - } \\
\text { mercaptoethan } \\
\text { ol for } 24 \mathrm{hrs}\end{array}$ \\
\hline Findings & $\begin{array}{l}81 \% \text { ESC } \\
\text { aggregates } \\
\text { showed } \\
\text { neurite } \\
\text { outgrowths. } \\
39 \% \text { of ESC } \\
\text { aggregates } \\
\text { differentiated } \\
\text { into neuron- } \\
\text { like cells. } \\
\text { The neurons- } \\
\text { like cells } \\
\text { expressed } \\
\text { class III } \beta \\
\text { tubulin, } \\
\text { neurofilament } \\
\text { L and M } \\
\text { subunit, } \\
\text { glutamate } \\
\text { receptor } \\
\text { subunits, } \\
\text { TTX-sensitive } \\
\text { sodium } \\
\text { channels and } \\
\text { voltage-gated } \\
\text { potassium } \\
\text { channels and } \\
\text { calcium } \\
\text { channels }\end{array}$ & $\begin{array}{l}\text { ESCs } \\
\text { differentiated } \\
\text { into a } \\
\text { homogenous } \\
\text { population of } \\
\text { neural } \\
\text { progenitors. } \\
\text { The neural } \\
\text { progenitors } \\
\text { expressed } \\
\text { markers for } \\
\text { pyramidal } \\
\text { neurons of the } \\
\text { cerebral cortex } \\
\text { (such as } \\
\text { VGLUT1/2). } \\
\text { After grafting } \\
\text { the neurons } \\
\text { showed axonal } \\
\text { projections, } \\
\text { which is } \\
\text { associated } \\
\text { with different } \\
\text { layers of the } \\
\text { cerebral } \\
\text { cortex. }\end{array}$ & $\begin{array}{l}\text { Neuroectoder } \\
\text { mal } \\
\text { differentiation } \\
\text { was greater } \\
\text { than } 80 \% \\
\text { when both } \\
\text { Noggin and } \\
\text { SB431542 } \\
\text { were used. } \\
\text { Neuroectoder } \\
\text { mal } \\
\text { differentiation } \\
\text { was less than } \\
\text { 10\% when } \\
\text { either Noggin } \\
\text { or SB431542 } \\
\text { used. } \\
\text { The Pax } 6^{+} \\
\text {neural crest } \\
\text { cells were } \\
\text { competent to } \\
\text { form } \\
\text { dopaminergic } \\
\text { and motor } \\
\text { neurons. }\end{array}$ & $\begin{array}{l}\text { After neural } \\
\text { induction of } \\
\text { NSCs with } \\
\text { IFN-- } \gamma \\
\text { The number of } \\
\text { NSCs } \\
\text { differentiated } \\
\text { into neurons } \\
\text { were } 8 \text { times } \\
\text { higher } \\
\text { compared to } \\
\text { controls in the } \\
\text { presence of } \\
100 \text { ng/ml } \\
\text { IFN- } \gamma \\
\text { differentiated } \\
\text { IFN- } \gamma \\
\text { increased the } \\
\text { expression of } \\
\text { JNK without } \\
\text { promoting } \\
\text { ERK1/2. }\end{array}$ & $\begin{array}{l}\text { Baicalin } \\
\text { induced NSCs } \\
\text { to extend } \\
\text { neurite } \\
\text { outgrowth, } \\
\text { express } \\
\text { neuronal } \\
\text { markers and } \\
\text { neurogenic } \\
\text { transcriptoinal } \\
\text { factors } \\
\text { Neuronal } \\
\text { differentiation } \\
\text { was induced } \\
\text { through } \\
\text { activation of } \\
\text { Erk1/2. }\end{array}$ & $\begin{array}{l}80 \% \text { of MSCs } \\
\text { differentiated } \\
\text { into neuronal } \\
\text { phenotype by } \\
\text { induction with } \\
\beta \text { - } \\
\text { mercaptoethan } \\
\text { ol } \\
\text { Neuronal cells } \\
\text { expressed } \\
\text { neurofilament- } \\
\text { M, neuron- } \\
\text { specific } \\
\text { enolase, tau } \\
\text { and nestin. }\end{array}$ \\
\hline
\end{tabular}


Ahmed et al., Int. Ann. Sci.; Vol. 8, Issue 1, pp: 38-46, 2020

Interestingly some somatic cells can be converted into a different a lineage directly, avoiding the conversion of the stem-like state as seen in iPSC reprogramming. Liu and others based in University of Colorado have demonstrated that fibroblasts can be directly reprogrammed into dopaminergic neuron in the presence of five transcription factors: Mash1, Ngn2, Sox2, Nurr1, and Pitx3 [25].

Another type of stem cells are multipotent stem cell, which have a limited range of differentiation compared to pluripotent stem cells. One example of multipotent stem cells is neural stem cells (NSCs), which differentiate into astrocytes, neurons and oligodendrocytes during neurogenesis. Previously it was thought that after adolescence the brain is post-mitotic. However intricate lineage tracing experiments and radioactive Carbon-14 isotope analysis has shown that NSCs exist in subventricular zone (SVZ) and in the dentate gyrus (DG) of the hippocampus of the adult brain generate neurons during adulthood [26], [27]. NSCs in the SVZ give rise to inhibitory GABAergic and dopaminergic interneurons of the olfactory bulb whilst NSCs in DG give rise to excitatory glutamatergic granule neurons. Moreover NSCs can be readily expanded and differentiated into different neurons in vitro types making it a potential good source of stem cell transplantation for AD. Kim et al has shown that NSCs can be readily differentiated into neurons in the presence of interferon $-\gamma$ and Li and colleagues have proposed that flavonoid Baicalin induces NSCs into neurons [28], [29].

Similarly mesenchymal stem cells are (MSCs) are a type of multipotent stem cells. Whether mesenchymal stem cells (aka mesenchymal stromal cells) are true stem cells are out scope of this review. MSCs can be harvested from several sources: adipose tissues, placenta, umbilical cord blood, bone marrow, muscles etc [30]-[33]. MSCs from the adipose tissue is preferred instead of bone marrow because the procedure is less invasive [34]. MSCs can be advantageous instead of using NSCs because of their ability to differentiate into multiple lineages including neurons. A paper published in 2000 shows that that MSCs can differentiate into neural lineages, expressing nestin, in the presence of $\beta$ mercaptoethanol [35].

\section{Approaches for Treating AD with Stem Cells}

The theoretical approaches for treating AD with stem cells can be classified into endogenous repair and exogenous repair (Table 3). In endogenous repair involves activating the already present stem cells, such as NSCs, in the brain. Since hippocampal neurogenesis is involved in learning and memory it is presumed that activating NSCs may halt or at least slow down regression of AD. NSCs can be activated and upregulated by using growth factors that play a role in neurogenesis, such as insulin growth factor-1, brain derived neurotrophic factor and vascular endothelial growth factor [36].

Exogenous repair involves stem cell transplants, i.e. stem cells are implanted into the atrophic area through surgery or injected intravenously. ESCs can be one source of stem cells for stem cell transplantation. A study published by Yue and colleagues have generated basal forebrain cholinergic neurons progenitors from ESCs. They transplanted the progenitors into the forebrain of $\mathrm{AD}$ animal rodent models and showed that the progenitors functionally integrated into the basal forebrain cholinergic projection system. Excitingly the mice model showed improvements in learning and memory [37].

Another commonly studied stem cell treatments in neurodegenerative animal models are MSCs. One group based in Egypt (Salem et al) compared bone marrow derived mesenchymal stem cells (BM-MSCs) with the conventional AD drugs (such as rivastigmine and cerebrolysin). They showed that the mesenchymal stem cells administered intravenously reached the brain. Compared to the commonly prescribed drugs for AD BM-MSCs showed cognitive improvements by upregulating expressions of choline acetyltransferase, survivin and nestin, which is a marker for neuronal progenitors [38]. Similarly, another group located in South Korea used adipose tissue derived mesenchymal stem cells (ADMSCs) as a source of stem cell based therapy. They indicated that the animal models used in 
their experiments had improvement cognition through increase in acetylcholine [39]. Interestingly MSCs can improve AD symptoms by other mechanisms. A study published by Shin et al in South Korea in 2014 in the journal autophagy revealed that MSCs improve the survival of neurons in the hippocampus in $\mathrm{AD}$ rodent models through neuroprotective effects. In their AD animal models administration of MSCs intravenously increased autosomal formation and $A \beta$ clearance [40].

Table 3: Novel stem cell treatments in animal models

\begin{tabular}{|c|c|c|c|c|}
\hline Study & [37] & [38] & [39] & [40] \\
\hline $\begin{array}{l}\text { Type of stem } \\
\text { cell }\end{array}$ & $\begin{array}{l}\text { Mouse and human } \\
\text { embryonic stem } \\
\text { cells }\end{array}$ & $\begin{array}{c}\text { Rat bone marrow } \\
\text { derived mesenchymal } \\
\text { stem cell }\end{array}$ & $\begin{array}{l}\text { Human adipose tissue- } \\
\text { derived mesenchymal stem } \\
\text { cells }\end{array}$ & $\begin{array}{c}\text { Human } \\
\text { mesenchymal stem } \\
\text { cells }\end{array}$ \\
\hline Model & $\begin{array}{l}\text { 5XFAD and } \\
\text { APP/PS1 AD } \\
\text { mice models }\end{array}$ & $\begin{array}{l}\text { AD induced in } \\
\text { Sprague-Dawley rats } \\
\text { by administering } \\
\text { aluminum chloride }\end{array}$ & $\begin{array}{l}\text { 18-month-old ICR mice } \\
\text { model }\end{array}$ & $\begin{array}{l}\text { 5-week-old ICR } \\
\text { mice and APP/ } \\
\text { PSEN1 double } \\
\text { transgenic mice } \\
\text { models }\end{array}$ \\
\hline $\begin{array}{l}\text { Delivery } \\
\text { route }\end{array}$ & $\begin{array}{l}8 \times 10^{4} \text { mouse or } \\
\text { humans BFNC } \\
\text { progenitors } \\
\text { injected bilaterally } \\
\text { into the basal } \\
\text { forebrain. }\end{array}$ & $\begin{array}{l}3 \times 10^{6} \text { BM-MSCs } \\
\text { /rat injected } \\
\text { intravenously } \\
\text { through the tail vein }\end{array}$ & $\begin{array}{l}\text { For intravenous } \\
\text { transplantation } 1 \times 10^{6} \\
\text { ADMSCs } / 100 \mu \mathrm{l} / \text { mouse } \\
\text { cells were injected and for } \\
\text { intracerebroventricular } \\
\text { transplantation } 4 \times 10^{5} \\
\text { ADMSCs } / 2 \mu \mathrm{l} / \text { mouse cells } \\
\text { were injected. }\end{array}$ & $\begin{array}{l}1.0 \times 10^{6} \mathrm{MSCs} \\
\text { were intravenously } \\
\text { injected through the } \\
\text { tail vein }\end{array}$ \\
\hline Findings & $\begin{array}{l}\text { ESCs } \\
\text { differentiated into } \\
\text { competent } \\
\text { BFCNs. } \\
\text { The grafts } \\
\text { differentiated into } \\
\text { functional mature } \\
\text { cholinergic } \\
\text { neurons and } \\
\text { integrated into the } \\
\text { basal forebrain } \\
\text { cholinergic } \\
\text { projection system. } \\
\text { Mice with cell } \\
\text { transplants } \\
\text { showed } \\
\text { improvements in } \\
\text { learning and } \\
\text { memory. }\end{array}$ & $\begin{array}{l}\text { BM-MSC crossed the } \\
\text { blood-brain barrier } \\
\text { and reached affected } \\
\text { areas of the brain. } \\
\text { The rats that received } \\
\text { treatment showed an } \\
\text { increase in } \\
\text { proliferation of } \\
\text { choline } \\
\text { acetyltransferase and } \\
\text { survivin labelled } \\
\text { cells. } \\
\text { The brains of rats that } \\
\text { received treatment } \\
\text { had a marked } \\
\text { decrease in A } \beta \\
\text { accumulation }\end{array}$ & $\begin{array}{l}\text { Transplanted ADMSCs } \\
\text { differentiated into neurones } \\
\text { and intro astrocytes. } \\
\text { The ADMSCs expressed the } \\
\text { expression of nerve growth } \\
\text { factor and brain-derived } \\
\text { neurotrophic factor. } \\
\text { Compared to controls mice } \\
\text { treated with ADMSCs had } \\
\text { improved physical and } \\
\text { cognitive performances. }\end{array}$ & $\begin{array}{l}\text { MSCs } \\
\text { administration } \\
\text { increased } \\
\text { expression of } \\
\text { Beclin 1, LC3-II } \\
\text { and autophagosome } \\
\text { induction in brain } \\
\text { tissue } \\
\text { Induction of } \\
\text { autophagic system } \\
\text { increased A } \beta \\
\text { clearance. } \\
\text { MSCs increased } \\
\text { cellular } \\
\text { survivability } \\
\text { through } \\
\text { neuroprotective } \\
\text { effects }\end{array}$ \\
\hline
\end{tabular}

\section{Clinical trials of stem cell therapy}

Before any treatment can be routinely performed in the hospital these treatments need to be evaluated in clinical trials to assess their efficacy and safety. At the moment most of the stem cellbased therapies clinical trials being conducted in 
Ahmed et al., Int. Ann. Sci.; Vol. 8, Issue 1, pp: 38-46, 2020

the last 10 years are at the phase I stage (Table 4). At this stage the safety and tolerability of the treatment are being measured on recruited patients diagnosed with the disease.

Table 4: Clinicals trials in the last 10 years

\begin{tabular}{|c|c|c|c|c|c|}
\hline $\begin{array}{l}\text { Trial } \\
\text { identifier }\end{array}$ & NCT01297218 & NCT02054208 & NCT02600130 & NCT02833792 & NCT02672306 \\
\hline Start date & February 2011 & February 2014 & August 2016 & June 2016 & October 2017 \\
\hline End date & December 2011 & July 2019 & March 2020 & June 2020 & October 2019 \\
\hline Phase & I & $\mathrm{I} / \mathrm{IIa}$ & I & IIa & $\mathrm{I} / \mathrm{II}$ \\
\hline $\begin{array}{l}\text { Study } \\
\text { design }\end{array}$ & $\begin{array}{l}\text { Open label, } \\
\text { single group } \\
\text { evaluating safety }\end{array}$ & $\begin{array}{l}\text { Randomized, } \\
\text { multiple dose } \\
\text { cohort study }\end{array}$ & $\begin{array}{l}\text { Randomized and } \\
\text { double-blinded } \\
\text { for assessing } \\
\text { safety and } \\
\text { efficacy }\end{array}$ & $\begin{array}{l}\text { Randomized, } \\
\text { crossover study } \\
\text { evaluating } \\
\text { efficacy and } \\
\text { safety }\end{array}$ & $\begin{array}{l}\text { Randomized and } \\
\text { double blinded } \\
\text { study assessing } \\
\text { efficacy and } \\
\text { safety }\end{array}$ \\
\hline $\begin{array}{l}\text { Inclusion } \\
\text { criteria }\end{array}$ & $\begin{array}{l}\text { Probable AD by } \\
\text { NINCDS- } \\
\text { ADRDA criteria, } \\
\text { positive for A } \beta \\
\text { by PIB-PET } \\
(\text { SUV > } 1.5)\end{array}$ & $\begin{array}{l}\text { Probable AD by } \\
\text { NINCDS-ADRDA } \\
\text { criteria, } \\
\text { positive for A } \beta \text { by } \\
\text { PIB-PET (SUV > } \\
1.5 \text { ) or Florbetaben } \\
\text { PET }\end{array}$ & $\begin{array}{l}\text { Probable AD by } \\
\text { NINCDS- } \\
\text { ADRDA } \\
\text { positive for A } \beta \\
\text { by PET using } \\
\text { AMYViD, } \\
\text { Vizamyl, or } \\
\text { Neuraceq tracers }\end{array}$ & $\begin{array}{l}\text { Probable AD by } \\
\text { NINCDS- } \\
\text { ADRDA criteria, } \\
\text { positive for A } \beta \\
\text { by Florbetaben } \\
\text { PET }\end{array}$ & $\begin{array}{l}\text { Probable AD by } \\
\text { NINCDS- } \\
\text { ADRDA criteria, } \\
\text { MMSE score } \\
\text { between } 10 \text { and } \\
26\end{array}$ \\
\hline $\begin{array}{l}\text { Type of } \\
\text { stem cells }\end{array}$ & $\begin{array}{l}\text { Human } \\
\text { Umbilical Cord } \\
\text { Blood Derived } \\
\text { Mesenchymal } \\
\text { Stem Cells }\end{array}$ & $\begin{array}{l}\text { Human Umbilical } \\
\text { Cord Blood } \\
\text { Derived } \\
\text { Mesenchymal } \\
\text { Stem Cells }\end{array}$ & $\begin{array}{l}\text { Allogeneic } \\
\text { Human } \\
\text { Mesenchymal } \\
\text { Stem Cell }\end{array}$ & $\begin{array}{l}\text { Allogeneic } \\
\text { Human } \\
\text { Mesenchymal } \\
\text { Stem Cells }\end{array}$ & $\begin{array}{l}\text { Umbilical Cord } \\
\text { Mesenchymal } \\
\text { Stem Cell }\end{array}$ \\
\hline $\begin{array}{l}\text { Subjects } \\
\text { enrolled }\end{array}$ & 9 & 45 & 38 & 40 & 16 \\
\hline Dosage & $\begin{array}{l}\text { Dose } A-3 \times 10^{6} \\
\text { cells per brain } \\
\text { DOSE B }-6 \times \\
10^{6} \text { cells per } \\
\text { brain }\end{array}$ & $\begin{array}{l}\text { Dose } \mathrm{A}-3 \\
\text { intraventricular } \\
\text { injections of } 1 \mathrm{x} \\
10^{7} \text { cells } \\
\text { Dose } \mathrm{B}-3 \\
\text { intraventricular } \\
\text { injections of } 3 \mathrm{x} \\
10^{7} \text { cells }\end{array}$ & $\begin{array}{l}\text { Dose A }-20 \mathrm{x} \\
10^{6} \text { cells per } \\
\text { peripheral } \\
\text { intravenous } \\
\text { infusion } \\
\text { Dose } \mathrm{B}-100 \mathrm{x} \\
10^{6} \text { per } \\
\text { peripheral } \\
\text { intravenous } \\
\text { infusion }\end{array}$ & $\begin{array}{l}1 \text { intravenous } \\
\text { injection of } 1.5 \mathrm{x} \\
10^{6} \text { per kg of } \\
\text { body weight }\end{array}$ & $\begin{array}{l}8 \text { intravenous } \\
\text { injection of } 20 \mathrm{x} \\
10^{6} \text { cells }\end{array}$ \\
\hline
\end{tabular}

One phase I clinical trial in 2011 conducted at Samsung Medical Center, South Korea evaluated the safety of using NEUROSTEM $\AA-A D$, which consists of human umbilical cord blood derived mesenchymal stem cells (Trial identifier: NCT01297218). In this trial 9 AD diagnosed patients were recruited and subjected to administration of NEUROSTEM $\AA$-AD into the hippocampus by stereotactic injection. 3 of these patients received low dose of NEUROSTEM ${ }^{\circledR}$ -
AD whilst the remaining 6 patients received high dose of NEUROSTEM®-AD. The patients were followed for 2 years and showed good tolerability without severe adverse side-effects [41]. In 2017 the Samsung Medical Center started the second phase clinical trial of this stem cell-based therapy to measure the efficacy of the treatment. It will be interesting to see clinical outcome of this trial, which is estimated to end in July 2019 (Trial 
identifier: NCT02054208). Similarly Longeveron LLC at United States has started a phase 1 clinical trial using allogeneic human mesenchymal stem cells (Trial Identifier: NCT02600130). This trial will recruit 25 subjects diagnosed with $\mathrm{AD}$ to investigate the safety and tolerability of the treatment. The trial participants will either receive high dose, low dose or placebo.

Moreover in the last 5 years 2 other stem cell based treatments have reached the phase II stage. One of the clinical trials is using mesenchymal stem cells and will assess the efficacy of the treatment (Trial Identifier: NCT02833792). This trial is expected to end in 2020. Likewise another Human Umbilical Cord-Derived Mesenchymal Stem Cells phase II trial is being conducted at South China Research Center for Stem Cell and Regenerative Medicine at China (Trial Identifier: NCT02672306). This study will evaluate the efficacy of the treatment and is expected to end in the last quarter of 2019.

\section{Perspective}

$\mathrm{AD}$ is one common form of dementia, affecting over 50 million people worldwide and placing a huge burden on society [1]. This neurodegenerative disease is well characterized by extreme atrophy in hippocampus and cerebral cortex due to neuronal death. At the moment the exact triggers that instigate the neuronal loss is controversial. There have been several hypotheses postulated; with the common ones being amyloid and tau hypotheses. There have been several novel treatments proposed agreeing with this hypothesis. Unfortunately the clinical trials showed no significant benefit or were terminated early because of ethical concerns with administering treatment to thousands of patients that are unlikely to work [11]. The failure of the clinical trials raises the following questions: is it time to completely abandon this hypothesis or shall we try to intervene at the earlier stages of the disease? If we want to intervene at the early stages of the disease, at the pre-symptomatic stage, we need to develop good biomarkers for the early phase of this disease.

Because of the failure of the clinical trials following the amyloid hypothesis has encouraged researchers to posit new ideas. One approach would be to promote neurogenesis by activating NSCs niches in SVG and DG of the brain. However neurogenesis drastically decreases with age and the rate of loss of neurons in $\mathrm{AD}$ is significantly more dramatic [36]. Also the upregulation of NSCs in SVG do not generate all neuronal subtypes and thus cannot repopulate pyramidal neurons of CA1, which is one of the neuronal subtypes affected in $\mathrm{AD}$ [42]. Therefore the rate of neurogenesis is unlikely to keep up with the rate of neuronal loss. Moreover in the later phases of AD the NSCs are not expected to survive therefore attempting to activate NSCs will not lead to any clinical benefit.

Another approach to treat AD would be exogenous repair, such as cell replacement therapy derived from stem cells. One source of stem cells are ESCs but the spontaneous propensity of ESCs to form teratocarcinomas and their ability to generate an immune response into the host necessitates caution for clinical use [43]. The issues of ESCs host rejection can be rectified by using an autologous therapeutic approach. In this method somatic cells are taken from the patient, reprogrammed into stem like state in vitro and then transplanted back into the patient. Furthermore iPSCs are less tumorigenic than ESCs because the mutations acquired during reprogramming are mostly benign [44]. However the $\mathrm{AD}$ risk genes that initially aggravates $\mathrm{AD}$ is likely to be present in the iPSCs derived cells and thus not actually curing the disease.

Before any of these novel treatments can be attempted on humans' researchers need to test them on animal models. Proof of concepts of these ideas have elicited encouraging results using ESCs as well as MSCs. Studies mentioned in this review have shown that stem cell treatments can improve learning and memory in rodents. However animal models used in these experiments obeyed amyloid hypothesis and therefore in my opinion do not fully recapitulate $\mathrm{AD}$ that is observed in humans.

In the last 10 year there have been several clinical trials registered for treating $\mathrm{AD}$ using stem cellbased therapy. Three have reached phase II where efficacy of the treatment is evaluated. It is too early to state whether stem cells will be 
Ahmed et al., Int. Ann. Sci.; Vol. 8, Issue 1, pp: 38-46, 2020

routinely used in the clinic because none have reached stage III and IV yet and can still fail.

\section{Conclusion}

Alzheimer's disease (AD) places a huge burden on the health agencies all of over the world. At the moment there is no cure for $\mathrm{AD}$ but it is theorized that cell replacement therapy is one potential mechanism of treating this disease. This review has explored several preclinical studies that showed that stem cell-based therapies improve cognition and memory in AD models. The impressive results from preclinical studies have paved the way for clinical trials. It is hoped that the information gained from these clinical trials will accelerate availability of stem cell-based therapies for all hospital patients suffering from AD.

\section{Competing Interest}

The authors declared that no conflict of interest exist in this publication.

\section{How to Cite this Article:}

J. Ahmed and H. Rahman, "Progression of Treating Alzheimer's Disease with Stem Cell-based Therapies", Int. Ann. Sci., vol. 8, no. 1, pp. 38-46, Jul. 2019. doi: 10.21467/ias.8.1.38-46

\section{References}

[1] A. Association*, "2019 Alzheimer's disease facts and figures," Alzheimer's Dementia, vol. 15, no. 3, pp. 321387, 2019.

[2] J. Xu, S. L. Murphy, K. D. Kochanek, and B. A. Bastian, "Deaths: Final Data for 2013.," National Vital Statistics Reports Centers Dis Control Prev National Cent Heal Statistics National Vital Statistics Syst, vol. 64, no. 2, pp. 1-119, 2016.

[3] A. Burns and S. Iliffe, "Alzheimer's disease," Bmj, vol. 338, no. feb05 1, p. b158, 2009.

[4] D. Campion et al., "Early-Onset Autosomal Dominant Alzheimer Disease: Prevalence, Genetic Heterogeneity, and Mutation Spectrum," Am J Hum Genetics, vol. 65, no. 3, pp. 664-670, 1999.

[5] C. Priller, T. Bauer, G. Mitteregger, B. Krebs, H. A. Kretzschmar, and J. Herms, "Synapse Formation and Function Is Modulated by the Amyloid Precursor Protein," J Neurosci, vol. 26, no. 27, pp. 7212-7221, 2006.

[6] H. Zheng and E. H. Koo, "The amyloid precursor protein: beyond amyloid," Mol Neurodegener, vol. 1, no. 1, p. 5, 2006.

[7] N. Arispe, E. Rojas, and H. Pollard, "Alzheimer disease amyloid beta protein forms calcium channels in bilayer membranes: blockade by tromethamine and aluminum.," Proc National Acad Sci, vol. 90, no. 2, pp. 567-571, 1993.
[8] A. Y. Abramov, L. Canevari, and M. R. Duchen, "Calcium signals induced by amyloid $\beta$ peptide and their consequences in neurons and astrocytes in culture," Biochimica Et Biophysica Acta Bba - Mol Cell Res, vol. 1742, no. 1-3, pp. 81-87, 2004.

[9] P. raiswamy et al., "Florbetapir F 18 amyloid PET and 36-month cognitive decline:a prospective multicenter study," Mol Psychiatr, vol. 19, no. 9, p. 1044, 2014.

[10] S. Gilman et al., "Clinical effects of A\&bgr; immunization (AN1792) in patients with $\mathrm{AD}$ in an interrupted trial," Neurology, vol. 64, no. 9, pp. 1553$1562,2005$.

[11] J. G. Hunsberger et al., "Accelerating stem cell trials for Alzheimer's disease," Lancet Neurology, vol. 15, no. 2, pp. 219-230, 2016.

[12] M. F. Egan et al., "Randomized Trial of Verubecestat for Prodromal Alzheimer's Disease," New Engl J Med, vol. 380, no. 15, pp. 1408-1420, 2019.

[13] J. Sevigny et al., "The antibody aducanumab reduces A $\beta$ plaques in Alzheimer's disease," Nature, vol. 537, no. 7618, p. 50, 2016.

[14] B. E. Reubinoff, M. F. Pera, C.-Y. Fong, A. Trounson, and A. Bongso, "Embryonic stem cell lines from human blastocysts: somatic differentiation in vitro," Nat Biotechnol, vol. 18, no. 4, p. nbt0400_399, 2000.

[15] M. Evans and M. Kaufman, "Establishment in culture of pluripotential cells from mouse embryos," Nature, vol. 292, no. 5819, p. 292154a0, 1981.

[16] G. Martin, "Isolation of a pluripotent cell line from early mouse embryos cultured in medium conditioned by teratocarcinoma stem cells," Proc National Acad Sci, vol. 78, no. 12, pp. 7634-7638, 1981.

[17] A. Wobus, R. Grosse, and J. Schöneich, "Specific effects of nerve growth factor on the differentiation pattern of mouse embryonic stem cells in vitro.," Biomed Biochim Acta, vol. 47, no. 12, pp. 965-73, 1988.

[18] G. Bain, D. Kitchens, M. Yao, J. E. Huettner, and D. I. Gottlieb, "Embryonic Stem Cells Express Neuronal Properties in Vitro," Dev Biol, vol. 168, no. 2, pp. 342$357,1995$.

[19] S. Okabe, K. Forsberg-Nilsson, C. A. Spiro, M. Segal, and R. McKay, "Development of neuronal precursor cells and functional postmitotic neurons from embryonic stem cells in vitro," Mech Develop, vol. 59, no. 1, pp. 89102,1996

[20] N. Gaspard, T. Bouschet, A. Herpoel, G. Naeije, J. van den Ameele, and P. Vanderhaeghen, "Generation of cortical neurons from mouse embryonic stem cells," Nat Protoc, vol. 4, no. 10, p. nprot.2009.157, 2009.

[21] K. Takahashi and S. Yamanaka, "Induction of Pluripotent Stem Cells from Mouse Embryonic and Adult Fibroblast Cultures by Defined Factors," Cell, vol. 126, no. 4, pp. 663-676, 2006.

[22] M. Stadtfeld, M. Nagaya, J. Utikal, G. Weir, and K. Hochedlinger, "Induced Pluripotent Stem Cells Generated Without Viral Integration," Science, vol. 322, no. 5903, pp. 945-949, 2008.

[23] T. Seki et al., "Generation of Induced Pluripotent Stem Cells from Human Terminally Differentiated Circulating T Cells," Cell Stem Cell, vol. 7, no. 1, pp. 11-14, 2010.

[24] S. M. Chambers, C. A. Fasano, E. P. Papapetrou, M. Tomishima, M. Sadelain, and L. Studer, "Highly efficient neural conversion of human ES and iPS cells by dual inhibition of SMAD signaling," Nat Biotechnol, vol. 27, no. 3, p. nbt.1529, 2009. 
[25] X. Liu et al., "Direct reprogramming of human fibroblasts into dopaminergic neuron-like cells," Cell Res, vol. 22, no. 2, p. cr2011181, 2011.

[26] F. Doetsch, I. Caillé, D. A. Lim, J. García-Verdugo, and A. Alvarez-Buylla, "Subventricular Zone Astrocytes Are Neural Stem Cells in the Adult Mammalian Brain," Cell, vol. 97, no. 6, pp. 703-716, 1999.

[27] K. L. Spalding et al., "Dynamics of Hippocampal Neurogenesis in Adult Humans," Cell, vol. 153, no. 6, pp. 1219-1227, 2013.

[28] S. Kim, T. Son, K. Kim, H. Park, M. P. Mattson, and J. Lee, "Interferon- $\gamma$ Promotes Differentiation of Neural Progenitor Cells via the JNK Pathway," Neurochem Res, vol. 32, no. 8, pp. 1399-1406, 2007.

[29] M. Li, K. Tsang, S. Choi, K. Li, P. Shaw, and K. Lau, "Neuronal Differentiation of C17.2 Neural Stem Cells Induced by a Natural Flavonoid, Baicalin," Chembiochem, vol. 12, no. 3, pp. 449-456, 2011.

[30] A. Friedenstein, I. Piatetzky-Shapiro, and K. Petrakova, "Osteogenesis in transplants of bone marrow cells.," $J$ Embryol Exp Morph, vol. 16, no. 3, pp. 381-90, 1966.

[31] H. . Goodwin et al., "Multilineage differentiation activity by cells isolated from umbilical cord blood: Expression of bone, fat, and neural markers," Biol Blood Marrow Tr, vol. 7, no. 11, pp. 581-588, 2001.

[32] K. Igura, X. Zhang, K. Takahashi, A. Mitsuru, S. Yamaguchi, and T. A. Takahashi, "Isolation and characterization of mesenchymal progenitor cells from chorionic villi of human placenta," Cytotherapy, vol. 6, no. 6, pp. 543-553, 2004.

[33] J. M. Gimble, A. J. Katz, and B. A. Bunnell, "AdiposeDerived Stem Cells for Regenerative Medicine," Circ Res, vol. 100, no. 9, pp. 1249-1260, 2007.

[34] S. Kern, H. Eichler, J. Stoeve, H. Klüter, and K. Bieback, "Comparative Analysis of Mesenchymal Stem Cells from Bone Marrow, Umbilical Cord Blood, or Adipose Tissue," Stem Cells, vol. 24, no. 5, pp. 1294-1301, 2006.

[35] D. Woodbury, E. J. Schwarz, D. J. Prockop, and I. B. Black, "Adult rat and human bone marrow stromal cells differentiate into neurons," J Neurosci Res, vol. 61, no. 4, pp. 364-370, 2000.

[36] T. Duncan and M. Valenzuela, "Alzheimer's disease, dementia, and stem cell therapy," Stem Cell Res Ther, vol. 8, no. 1, p. 111, 2017.

[37] W. Yue et al., "ESC-Derived Basal Forebrain Cholinergic Neurons Ameliorate the Cognitive Symptoms Associated with Alzheimer's Disease in Mouse Models," Stem Cell Rep, vol. 5, no. 5, pp. 776790, 2015.

[38] A. M. Salem, H. H. Ahmed, H. M. Atta, M. A. Ghazy, and H. A. Aglan, "Potential of bone marrow mesenchymal stem cells in management of Alzheimer's disease in female rats," Cell Biol Int, vol. 38, no. 12, pp. 1367-1383, 2014.

[39] D. Park et al., "Human adipose tissue-derived mesenchymal stem cells improve cognitive function and physical activity in ageing mice," J Neurosci Res, vol. 91, no. 5, pp. 660-670, 2013.

[40] J. Shin et al., "Mesenchymal stem cells enhance autophagy and increase $\beta$-amyloid clearance in Alzheimer disease models," Autophagy, vol. 10, no. 1, pp. 32-44, 2013.

[41] H. Kim et al., "Stereotactic brain injection of human umbilical cord blood mesenchymal stem cells in patients with Alzheimer's disease dementia: A phase 1 clinical trial," Alzheimer's Dementia Transl Res Clin Interventions, vol. 1, no. 2, pp. 95-102, 2015.

[42] D. Davies, N. Horwood, S. Isaacs, and D. Mann, "The effect of age and Alzheimer's disease on pyramidal neuron density in the individual fields of the hippocampal formation," Acta Neuropathol, vol. 83, no. 5, pp. 510-517, 1992.

[43] R.-J. Swijnenburg et al., "Immunosuppressive therapy mitigates immunological rejection of human embryonic stem cell xenografts," Proc National Acad Sci, vol. 105, no. 35, pp. 12991-12996, 2008.

[44] K. Bhutani et al., "Whole-genome mutational burden analysis of three pluripotency induction methods," Nat Commun, vol. 7, no. 1, p. 10536, 2016.

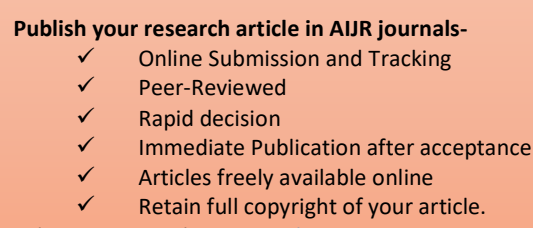

Publish your books with AIJR publisherPublish with ISBN and DOI. Publish Thesis/Dissertation as Monograph. Publish Book Monograph. Publish Edited Volume/ Book. Publish Conference Proceedings Retain full copyright of your books. Submit your manuscript at books.aijr.org 